\title{
FORTIFICATIONS FROM THE LATE IRON AGE IN THE REGIONS OF POHRONIE AND POIPLIE ${ }^{1}$
}

\author{
B R A N I S L A V K O V Á R 문
}

\begin{abstract}
Fortified sites from the La Tène Period belong to the main research topics of Karol Pieta. He has contributed to their field excavations in the mountainous environment of Slovakia to a great extent. He also very intensely deals with their classification and dating. In the text, I try to apply his knowledge on the research of the fortified sites in the regions of the Hron and Ipel' river basins and also confront them with the latest research. K. Pieta has distinguished several types of fortifications: hillfort, castella, small hillfort, refuge place, etc. Unlike other authors, he did not consider only the size of the fortified area, but also its use. Individual fortifications and enclosed areas might have had a practical function, social or symbolic meaning. K. Pieta promotes mainly the defensive and protective function of the fortified sites in the territory of Slovakia. There had to be real reasons and favourable conditions for existence of fortifications, as they were often large structures challenging as for work power and its organization, project with some experience as well as available sources of building material and strategical thinking of the authors. Nevertheless, he does not exclude possible central, commercial or sacral function of the fortified settlements. I have selected the regions of Pohronie and Poiplie in the analysis for three reasons - they are more or less complexly processed and their character allows application of results also for other parts of the north of the Carpathian Basin, maybe with the exception of the area of the Bratislava oppidum. The third characteristics of the chosen region which was the reason for selecting it as a 'model' is that it is partly a peripheral area of the La Tène settlement in the north of the Carpathian Basin, where two cultural areas meet the La Tène and Púchov cultures. According to the current state of research, there are 26 fortified sites of different sizes and forms in the area.
\end{abstract}

Keywords: Slovakia, La Tène Period, fortifications, hillforts.

The topic of fortifications from the La Tène and other historical periods is one of the topics which celebrator Dr. Karol Pieta ${ }^{2}$ deals with. He focused mainly on the research of montane settlement in the territory of Slovakia. Other areas studied by him included the mountainous parts of the Hron and Ipel' river basins. He personally studied several fortifications there - not only from the Iron Age. He has also greatly contributed to the definition of fortified settlements from the late Iron Age. In the article (essay), I will focus on perception of fortifications from the Hron and Ipel river basins in the La Tène Period from the aspect of research and from K. Pieta's point of view.

We detect fortified or enclosed sites in Europe since the Neolithic (Harding/Sievers/Venclová 2006). This applies to the northern part of the Carpathian Basin as well. In the Iron Age, we observe exponential increase in the number of fortifications in Western Europe (Romankiewicz et al. 2019, 1). Unlike the neighbouring Czech Republic (Salač ed. 2019) or the British Isles (Halliday 2018, 37-51), there is no complex registry of hillforts for the territory of northern Carpathian Basin, therefore, we cannot confirm similar conclusions, although we can assume them. Fortifications occurred rather frequently in the La Tène Period in the regions of the Hron and Ipel' river basins.

How should we define the concepts of fortified place, hillfort or fortification? Can refuges without fortifications be classified in these categories? Did oppida occur in the north of the Carpathian Basin? We have brief reports on fortifications from the Iron Age by antique authors, although none of them refers to the north of the Carpathian Basin. The famous Greek philosopher Herodotos mentions the town of Paréné (or Pyrene), which could be identified with the fortified settlement from the Early Iron Age - Heuneburg (Herodotos 2, 33). The note of Roman statesman Gaius I. Caesar on a Gallic wall - murus gallicus (Caesar 7, 23) is known as well. This description was also confirmed by archaeological excavations. Murus gallicus contains a massive box construction from alternating transversely and

\footnotetext{
1 The text is written as part of projects VEGA 2/0124/20: Medieval economy ( $6^{\text {th }}-13^{\text {th }}$ centuries) and VEGA 01/0240/21: The landscape and settlements of the Celts and Germans. Mutual relations, relations in and with the landscape.

2 I wish to express my sincere gratitude to Dr. Karol Pieta for all his advice and help on my archaeological journey.
} 
longitudinally laid beams; the ends of transverse beams ended in the face of the stone wall. This type of defensive wall was common mainly in the west and in the Alpine territory, it met a different type of construction which was used especially in central Europe. Its foundations consisted of a row of vertical poles in the front defensive wall which were connected with the back line of poles (Altkönig/Priest) or with a rampart (Kelheim type) with horizontal woods. However, there are several variations of both construction elements (Audouze/Buchsenschutz 1992, 85-104; Buchsenschutz/Ralston 1981; Collis/ McLaren/Ralston 1976; Pieta 2008, 110).

The topic of hillforts from the La Tène Period in the territory of Slovakia has been dealt with by several researchers. The Little Carpathian site of Pohanská in Plavecké Podhradie was studied by J. Paulík (1976), K. Pieta $(2008,112)$ and R. Čambal (2015). A. Točík (1981) and G. Březinová $(2010 ; 2012)$ studied La Tène fortifications at the polycultural site of Šurany-Nitriansky Hrádok-Zámeček. P. Čaplovič (1987) dealt with hillforts in Orava. P. Šalkovský studied and processed the site in Detva-Kalamárka (Benediková/Kovár 2007, 143-160; Šalkovský 1994; 2001; 2002). Fortifications in the region of Liptov were studied mainly by M. Furman (2016). K. Pieta scientifically studied several fortified sites from the Iron Age, in northern Slovakia in the environment of the Púchov culture (Liptovská Mara ${ }^{3}$ I-Havránok, Kvačany-Hrádková, Nemecká-Hradisko, Horná Lehota-Hrádok, Trenčianske BohuslaviceMalovecké, Folkušová-Havrania skala, NecpalyBrotnice and others) as well as in southwestern Slovakia (Bratislava-Devín, Horné Orešany-Slepý vrch, Plavecké Podhradie-Pohanská; Pieta 2008; 20104). He investigated some sites in northern Slovakia together with L. Benediková (e.g. Liptovský Trnovec-Hrádok, Liptovské Matiašovce-Nad Konislavou, Liptovský Trnovec-Opálenica; Benediková/Pieta 2018, 147-196). ${ }^{5}$

\section{DEFINITION OF A FORTIFIED AREA}

Archaeological literature identifies fortified sites from the La Tène Period as hillforts (hradisko in Slovak) or small hillforts (hrádok in Slovak) and points mainly to their defensive and central function. It might be more accurate to call these areas 'enclosed or fortified areas', i.e. they are enclosed places which physically or conceptually delimit a certain area. Entrance in this area is limited and controlled. The place can be enclosed by a rampart, ditch, palisade or a fence. People might have used natural elements for enclosing - steep slopes, swamps or rivers. Therefore, archaeologists do not necessarily detect the 'enclosure' with their research methods (Harding 2012, 1-6).

In the Slovak archaeological investigation, the opinion is predominant that the hilly terrain of the Carpathian Basin is more than suitable for building fortifying structures (e.g. Pieta 2008, 110). Fortifications from the La Tène Period are often associated with mountainous terrain. Nevertheless, we must not forget that La Tène fortifications are not necessarily located on hills (Harding 2012, 1). The more frequent fortifications in the mountain environment in the territory of Slovakia might only reflect the state of research, not the historic reality. Building fortifications in the montane environment in the Late Iron Age can be preconditioned by the suitable terrain in Slovakia.

In his work dedicated to the La Tène settlements, J. Collis defined three types of settlement sites in Slovakia - settlements of the Zemplín type, hillforts and open settlements (Collis 1975, 70-73). Besides the eponymous site (Zemplín-Hrádok) studied by B. Benadik (1965), V. Budinský-Krička, E. Miroššayová (2019) ${ }^{6}$, D. Čaplovič (Miroššayová/Čaplovič 1991), L. Luštiková (Luštíková/Miroššayová 2009) and M. Ruttkay (in press), he classified a combination of a fortified site with an unfortified settlement (settlements) nearby in the same type, such as BratislavaDevín (Pieta/Plachá/Hlavicová 1986; Plachá 1972; 1991) and Nitra (Bednár/Březinová/Ptáčková 2005; Březinovál Chroporský 2020). J. Collis also distinguished the category of hillforts, where he includes mainly the fortified sites from the Púchov culture environment as well as the La Tène site of Šurany-Nitriansky Hrádok-Zámeček, further to the south. The last category in his classification contained open settlements where he included e.g. the area of Bratislava (Collis 1975, 70-73). Collis's typology was influenced by the then state of research. For instance, it is questionable to what extent the oppidum in Bratislava can be classified among open settlements. We don't have a lot of information about open settlements ${ }^{7}$ of the Nermčice-Roseldorf type in the north of the Carpathian Basin (ČižmářlKolníková 2006; Čižmár̆l Kolníková/Noeske 2008; Salač 2005, 290-292), but we

\footnotetext{
3 And other sites here - Liptovská Mara II-VII.

4 See more literature there.

5 I wish to thank my colleague L. Benediková for consultations regarding this text.

6 You can find more literature about hillfort from Zemplín here.

7 G. Březinová (2006) processed open settlement from Slovakia.
} 
can consider that archaeological locations from Nitra-Zobor (Šindolka, Martinský vrch), NitraChrenová (II, III), Nitra-Mikov Dvor (Rozvodňa elektriny) have features this type (Březinová 2000; Březinová/Chropovský 2020).

Z. Smrž considers only division of upland sites into hillforts, i.e. sites with man-made fortification, and upland settlements which must have natural protection from three sides at least (Smrž 1991, 63).

D. Harding divided fortified (or rather enclosed) sites in a simpler way, i.e. by their size - oppida, large, medium and small hillforts. He classified sites of 1-30 ha among large hillforts. Oppida were spreading over areas larger than 30 ha (Harding 2012, 8, 9).

K. Pieta understood the concepts of hillfort, small hillfort, fortification, or refuge place as something used to protect individuals or groups of people with use of natural or artificial barriers placed between the defender and the attacker. In his opinion, even the oldest fortifications were not created accidentally, they required careful logistic preparation which must have considered the capacity, material and technical possibilities of protection and the assumed aims of the offender (Fichtl 2000, 53, 54; Pieta 2008, 109).

K. Pieta divided fortifications in five categories (Pieta 2008, 120-126): hillforts (with the sub-category of oppida), small centres - castella, small hillforts, refuge places and linear protective structures. K. Pieta includes larger fortified areas usually of several hectares in the category of hillforts. Within the category of hillforts, he distinguishes a separate sub-category of oppida which he defines as fortified central settlements and includes Bratislava (it is approx. 60 ha with baileys), Plavecké Podhradie (49 ha), Bratislava-Devín (9.5 ha), Smolenice (9 ha) and Trenčianske Bohuslavice (9 ha) among them. He includes the Zemplín type in the category of hillforts. ${ }^{8}$ In this type, he classifies smaller hillforts with the function of some kind of a fortified acropolis (e.g. the site of Liptovská Mara, 1.6 ha) which could have been used basically only as refuges. Unfortified settlements were located in their vicinity. D. W. Harding $(2012,8)$ divides hillforts in a similar way. K. Pieta see different development between west side and east site of the Carpathia. We can see large urban settlements (Oberleiserberg, Staré Hradisko) on the west. The settlements located east of the Hungarian Gate have a different appearance. They are characterized by their fortifications, around which the production settlements are concentrated (Zemplín type; Pieta 2001, 784).
Small centres, so-called castella, are described by K. Pieta as smaller hillforts with permanent settlement, often with traces of intense crafts. He presents the site of Šurany-Nitriansky Hrádok-Zámeček (1.6 ha) as an example (Pieta 2008, 121). ${ }^{9}$

Pieta's third distinguished category includes small hillforts. They are small fortified sites whose size does not exceed $1 \mathrm{ha}$. They are often very small and they might have had the function of a kind of fortified farmsteads of important individuals or they had strategical function and protected smaller settlement units in the hilly landscape. They might have been located also inside larger older prehistoric or La Tène fortifications. In the environment of northern Slovakia, they were situated at foothills, where small hillforts, often open settlements, were located. The site of Kvačany-Hrádková (0.18 ha; Pieta $2008,121-125)$ is a typical example.

Use of natural protective qualities of the location for protection of the inhabitants or their properties is a characteristic feature of refuge places. If they were fortified, it was not done along the whole circumference, remains of older fortifications could have been used, like in the case of the site called Katova skala in Sklabinský Podzámok (Pieta 2008, 125).

The last category comprises linear protective structures. They are fortifications with either only temporary function or they delimited a certain territory (a border). They are often not spatially closed. The system of fortifications from the site of Podturen is an example (Pieta 2008, 126).

The categories distinguished by K. Pieta bring a certain system in the categorization of fortifications in the La Tène Period in the territory of Slovakia. However, the borders between individual types are often unclear and influenced by the state of research at the particular site. In the Slovak archaeological literature, three names for different types of Iron Age fortification occur most frequently - hillforts, small hillforts and refuge places. Authors rarely present the exact difference between hillforts and small hillforts. Hillforts are mostly vaguely defined as areas larger than other fortified sites. It is also difficult to distinguish between hillforts and refuge places. Oppida should be defined more precisely as well.

Individual fortifications and enclosed areas may have had a practical function, a social or symbolic meaning. The practical function of fortifications and enclosed areas lies mainly in creation of barriers preventing e.g. children or farm animals from getting lost. According to E. Neustupný, fortification has a social meaning especially from the aspect of defence (it protects the whole society). There is also

\footnotetext{
8 We can suppose that site Nitra-castle is from the same category (BřezinoválChropovský 2020).

9 After new research by G. Březinová (2010) is possible that site is from different category (Zemplín type?).
} 
creation of a commercial centre within the fortified area. The symbolic meaning of fortifications can be associated mainly with the identity of the society. For instance, hillforts can be used as a symbol of larger communities. They help define 'our space' against 'their space' (Neustupny 2006, 1-4). The symbolic meaning can also be associated with specification of a sacral space. For instance, at the hillfort of Glauberg from the Iron Age, where - apart from settlement areas - burial grounds were discovered, it is assumed that parts of the fortifications symbolically divided the world of the dead from the world of the living (Posluschny 2019, 9-18).

K. Pieta promotes mainly the defensive and protective functions of the fortified sites in the territory of Slovakia. There must have been real reasons and favourable conditions for creation of fortifications, since they were often extensive constructions requiring work power and its organization on a high level as well as project of the construction with experience, available sources of building material and strategical thinking of the authors. At the same time, he does not exclude possible central, production or sacral function of the fortified settlements (Pieta 2008, 69-76).

\section{THE UPPER HRON AND IPEL'RIVER BASINS - FORTIFICATIONS}

The regions of Pohronie and Poiplie are defined by the Hron and Ipel' river streams in this text. The studied area, however, is wider from the geographical point of view, therefore I include the nearby sites from the regions of Polana and the Štiavnické vrchy hills in it. They are the areas where the La Tène (the lower Hron and Ipel' river basins) and Púchov cultures of the Late Iron Age were spread. I have chosen the region as an example for three reasons - it is more or less complexly processed (Beljak 2006; Beljak/Beljak Pažinová/Mitáš 2015; Beljak/Kučeráková 2015; Březinová 2006; Kovár 2016) and its character allows application of the results on other parts of the north Carpathian Basin, probably with the exception of the area of the oppidum in Bratislava. The third characteristics of the selected region due to which I have chosen the area as a 'model' is that it is partly a peripheral territory of the La Tène settlement in the north of the Carpathian Basin, where two cultural spheres meet (La Tène and Púchov cultures). We must point to the fact that some of the following conclusions are conditioned by the state of research, as e.g. no fortified settlements have been recorded on the Hungarian side of the Ipel' river basin so far (Kovár 2016, 221).
We cannot assume continuous settlement in stage LTA on the majority of the studied Pohronie and Poiplie territory. Survival of the Hallstatt population (the Vekerzug and Lusatian cultures) in the La Tène Period also remains an unanswered question, although it is suggested by some finds. The Vekerzug culture might have survived in the region until as late as stage LTC1 (Kovár 2016, 223). In the course of stage LTB, density of settlement increased mainly in the territory of the lower Hron and Ipel' river basins. It is probably associated with penetration of the expanding Celtic ethnic group from the west (Bujna 1994, 9). In the Middle La Tène Period (stages LTB2/LTC1 to LTC1), density of settlement in the region is still increasing. Relics of the so-called Pre-Púchov stage occur in the upper Hron river basin in that period. In the Late (LTC2) and Final La Tène Period (LTD), density of settlement seems to be decreasing. It was expressed most significantly in stage LTD. This fact, however, does not apply to the upper Hron river basin, which became a domain of the Púchov culture (Kovár 2016, 223-225).

We have recorded two types of settlements in the Upper Hron river basin - open and fortified settlements. Open settlement means a site without discovered man-made (ramparts, ditches) or natural (inaccessible terrain) fortification elements. Many sites from the regions of Pohronie and Poiplie are indicated as settlements in literature, however, there is often only ceramic material, often fragmentary. We know several hundreds of La Tène sites in the region (Beljak/Beljak Pažinová/Mitáš 2015; Kovár 2016). Only the sites with identified settlement features (houses, storage pits, etc.) or cultural layers or numerous archaeological finds allowing assumptions of an inhabited area can be definitely identified as settlements. Settlement features from the Late Iron Age in southern Slovakia were located at the following sites: ${ }^{10}$ Barca-Kovalcsík (Kovács 1982; 1989), Bielovce-Telek (Fusek 1986), Breznica (Mosný 1988), Čaka (Vladár 1962), Chlaba (Bujna 1980; Hanuliak 1989), Slovenské Ďarmoty (Vendtová 1964), Šarovce (Kuzmová 1980; Novotný 1955), Tekovský Hrádok (Kujovský 1985), Včelince-Lászlófala (Furmánek/Marková 1986; Kovács 1984) and Stránska (Rusnák 2007). Further investigation could confirm existence of other settlement features. Settlement features were also discovered at fortified sites - at Kalamárka in Detva (Šalkovský 2002) and Hronská Dúbrava-Trnavá Hora-Hrádok (Pieta 2008, 37; Pieta/Mosný 1990a; 1999). ${ }^{11}$

26 sites from the La Tène Period with documents of fortification or at locations with extreme terrain properties which were probably used as protective

\footnotetext{
10 The chronology of sites is by authors of research. It is possible that it will be changed after the next excavation.

${ }^{11}$ In literature, the site is localized in cadastral areas of two villages.
} 
Tab. 1. Fortifications from the Late Iron Age in the regions of Pohronie and Poiplie. The chronology of sites is by authors of the research. It is possible that it will be changed after the next excavation.

\begin{tabular}{|c|c|c|c|c|c|c|}
\hline & Site & Altitude [m] & $\begin{array}{c}\text { Extent } \\
\text { of fortification }\left[\mathrm{m}^{2}\right]\end{array}$ & $\begin{array}{c}\text { Type } \\
\text { of fortification }\end{array}$ & Chronology & References \\
\hline 1. & Badín & - & - & - & LTD & Pieta 2008, 40 \\
\hline 2. & Banská Bystrica-Hôrka & 439 & - & - & LTB2/LTC1-LTD2 & Budinský-Krička 1947 \\
\hline 3. & Bzenica-Sobotište & 392.2 & - & rampart & $\begin{array}{l}\text { LTB2/LTC1- } \\
\text { LTC2/LTD1 }\end{array}$ & $\begin{array}{l}\text { Beljak/Kučeráková 2015, 11; } \\
\text { Mosný 1988; Pieta 2008, } 41\end{array}$ \\
\hline 4. & Čebovce-Zámok & 437 & - & rampart & LTC1-LTC2 & Čambal/Kovár 2014 \\
\hline 5. & Detva-Kalamárka & 808.3 & 10,000 & rampart & $\begin{array}{l}\text { LTA, LTB, LTC, } \\
\text { LTD }\end{array}$ & Šalkovský 2002 \\
\hline 6. & Horná Lehota-Hrádok & 834 & 2,400 & $\begin{array}{l}\text { rampart, } \\
\text { gate? }\end{array}$ & LTB-LTC1 & $\begin{array}{l}\text { Mácelová 1992; Pieta/Mosný } \\
\text { 1996b; 2000; 2001; } 2002\end{array}$ \\
\hline 7. & Horné Pršany-Hrádok & 660 & 4,200 & rampart & - & Petrikovich 1947; Pieta 1993 \\
\hline 8. & Hrochot'-Chochulka & - & - & - & - & Beljak/Kučeráková 2015, 8 \\
\hline 9. & $\begin{array}{l}\text { Hronská Dúbrava/ } \\
\text { Trnavá Hora-Hrádok }\end{array}$ & 416.2 & $1,840-2,100$ & rampart & LTB2/LTC1-LTC1 & $\begin{array}{l}\text { Pieta 2008, 37, 122; } \\
\text { Pieta/Mosný 1990a; } 1999\end{array}$ \\
\hline 10. & Lieskovec-Hrádok & - & - & - & - & $\begin{array}{l}\text { Beljak/Kučeráková 2015, 11; } \\
\text { Mosný } 1986\end{array}$ \\
\hline 11. & Lučatín-Hradište & - & - & - & - & $\begin{array}{l}\text { Beljak/Kučeráková 2015, 11; } \\
\text { Mosný } 1990\end{array}$ \\
\hline 12. & Málinec & - & - & - & - & Pieta 2008, 37 \\
\hline 13. & Nemecká & 786 & - & rampart & - & $\begin{array}{l}\text { Mácelová 1995; } \\
\text { Mácelová/Mosný/Pieta 1997; } \\
\text { Pieta/Mosný 1996a }\end{array}$ \\
\hline 14. & Podzámčok hrad Dobra Niva & 347 & - & - & - & Beljak/Kučeráková 2015, 11 \\
\hline 15. & Ponická Huta & 580 & - & rampart & LTC1-LTC2 & Pieta 2008, 37 \\
\hline 16. & Rybník-Krivín & 315 & $470,000-510,000$ & $\begin{array}{l}\text { rampart, } \\
\text { gates }\end{array}$ & LTA?, LTB?, LTD2 & $\begin{array}{l}\text { Furmánek 1969; } \\
\text { Veliačik/Srnka/Valo } 2002\end{array}$ \\
\hline 17. & Selce-Hrádok & 780 & - & - & LTB/LTC- LTD2 & $\begin{array}{l}\text { Mácelová 1980; Mosný, undated; } \\
\text { Pieta 1989; 1990; 2008, } 40\end{array}$ \\
\hline 18. & Sielnica-Hrádok & - & - & - & - & Beljak/Kučeráková 2015, 11 \\
\hline 19. & Stará Bašta-Pohanský vrch & $436.2-577.9$ & 420,000 & rampart & - & Furmánek 1996; 1997 \\
\hline 20. & Stará Kremnička & 408,1 & - & - & - & Pieta 2008, 37 \\
\hline 21. & $\begin{array}{l}\text { Šášovské Podhradie/ } \\
\text { Žiar nad Hronom-Sut' }\end{array}$ & 718 & - & - & - & Pieta 2008, 37 \\
\hline 22. & $\begin{array}{l}\text { Šášovské Podhradie/ } \\
\text { Žiar nad Hronom-castle Šášov }\end{array}$ & - & - & - & - & Beljak/Kučeráková 2015, 11 \\
\hline 23. & Širkovce-castle & - & - & - & - & Furmánek/Sankot 1985, 275 \\
\hline 24. & Zvolen-Pustý hrad & $478.3-571.4$ & - & - & - & Beljak/Kučeráková 2015, 8 \\
\hline 25. & Zvolen-Vel'ká Stráž & - & - & rampart & - & Beljak/Kučeráková 2015, 11 \\
\hline 26. & Žiar nad Hronom & - & - & - & LTC2, LTD & Pieta 2008, 37 \\
\hline
\end{tabular}


elements have been identified in the defined area so far (Fig. 1; Tab. 1). The available sources on some sites do not mention whether there is any evidence of fortification, but as they are located at altitudinally exposed places and are often small, we can assume their refuge function.

We have documented several fortified and upland sites from the studied area ${ }^{12}-$ Badín (Pieta 2008, 40), Banská Bystrica-Hôrka (Budinský-Krička 1947), Bzenica-Sobotište (Beljak/Kučeráková 2015, 11; Mosný 1988; Pieta 2008, 37-41), Čebovce-Zámok (Čambal/Kovár 2014), Detva-Kalamárka (Šalkovský 2002), Horná Lehota-Hrádok (Mácelová 1992; Pietal Mosný 1996a; 2000; 2001; 2002), Horné PršanyHrádok (Petrikovich 1947; Pieta 1993), HrochotChochulka (Beljak/Kučeráková 2015, 8), Hronská Dúbrava-Trnavá Hora-Hrádok (Pieta 2008, 37; Pieta/Mosný 1990a; 1999), Lučatín-Hradište (Beljak/ Kučeráková 2015, 11; Mosný 1990), Málinec (Pieta 2008, 37), Nemecká-Hradisko (Mácelová 1995; Mácelová/Mosný/Pieta 1997; Pieta/Mosný 1996a), Ponická Huta-Poniky (Pieta 2008, 37), Rybník-Krivín (Furmánek 1969; Veliačik/Srnka/Valo 2002), SelceHrádok (Mácelová 1980; Mosný, undated; Pieta 1989; 1990), Sielnica-Hrádok (Beljak/Kučeráková 2015, 11), Stará Bašta-Pohanský hrad (Furmánek 1996; 1997), Stará Kremnička (Pieta 2008, 37), Šášovské Podhradie/Žiar nad Hronom-Sut' (Pieta 2008, 37), Zvolen-Vel'ká Stráž (Beljak/Kučeráková 2015, 11) and Žiar nad Hronom (Pieta 2008, 37). Settlement from the La Tène Period was probably also present at medieval castles, such as Dobrá Niva-Podzámčok (Malček 2000), Širkovce (Furmánek/Sankot 1985, 275), Šášov in Šášovské Podhradie/Žiar nad Hronom, Lieskovec-Hrádok (Beljak/Kučeráková 2015, 11) and in Zvolen-Pustý hrad (Beljak/Kučeráková 2015, 8). At medieval castles, later construction might have destroyed older fortifications.

The hillforts in Detva-Kalamárka (808.3 m a.s.l.), Horná Lehota-Hrádok (834 m a.s.l.) and NemeckáHradisko (786.3 m a.s.l.) were situated at the highest locations. The largest system of fortification is found at the hillforts of Krivín near Rybník (approx. 47-51 ha) and Stará Bašta-Pohanský hrad (approx. 42 ha). Nevertheless, both sites were settled in longer periods and the extent of their use in the La Tène Period will be subject to further investigation.

With the exceptions of the sites in ČebovceZámok, Detva-Kalamárka, Málinec and Stará BaštaPohanský hrad, all fortified sites were located in the upper Hron river basin,,$^{13}$ which can be associated with the character of the natural environment, as well as the state of research, which could be con-

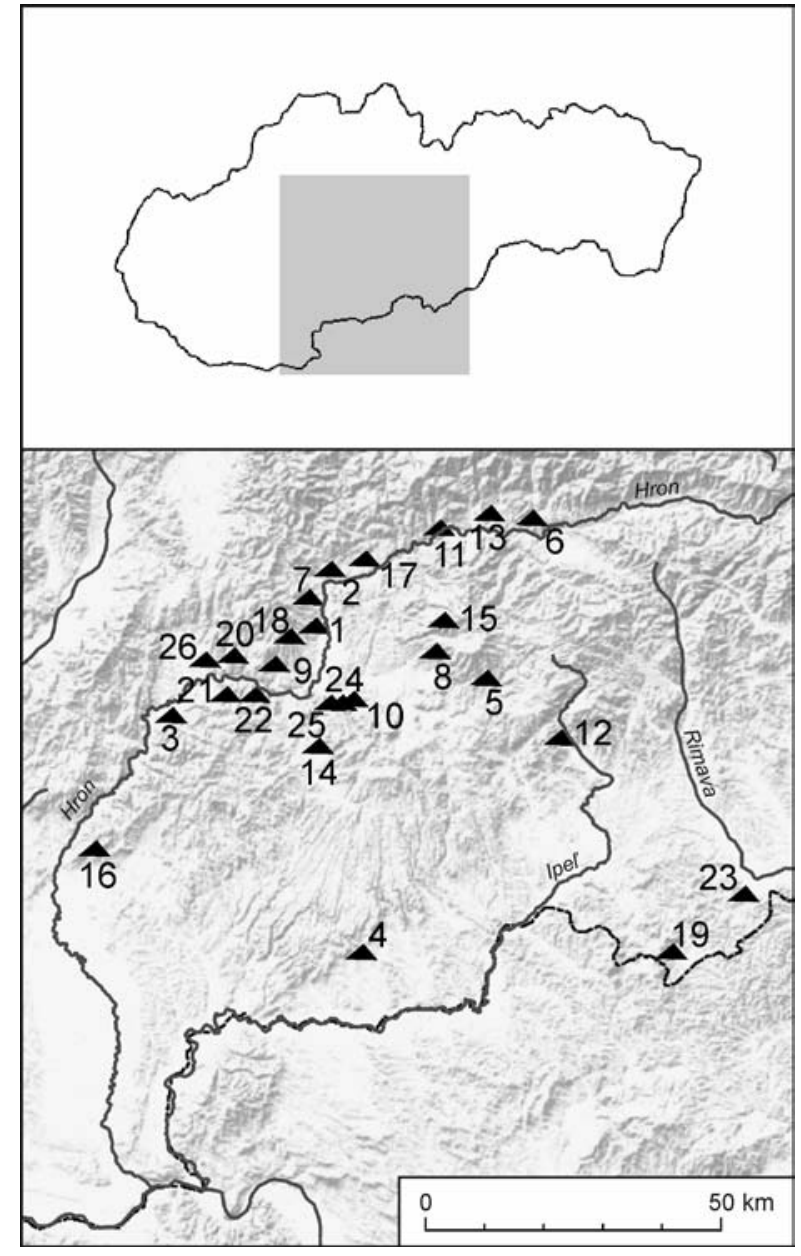

Fig. 1. Fortifications from the Late Iron Age in the regions of Pohronie and Poiplie. 1 - Badín; 2 - Banská BystricaHôrka; 3 - Bzenica-Sobotište; 4 - Čebovce-Zámok; 5 Detva-Kalamárka; 6 - Horná Lehota-Hrádok; 7 - Horné Pršany-Hrádok; 8 - Hrochot'-Chochulka; 9 - Hronská Dúbrava/Trnavá Hora-Hrádok; 10 - Lieskovec-Hrádok; 11 Lučatín-Hradište; 12 - Málinec; 13 - Nemecká-Hradisko; 14 - Podzámčok castle Dobra Niva; 15 - Ponická Huta; 16 Rybník-Krivín; 17 - Selce-Hrádok; 18 - Sielnica-Hrádok; 19 - Stará Bašta-Pohanský hrad; 20 - Stará Kremnička; 21 Šášovské Podhradie/Žiar nad Hronom-Sut; 22 - Šášovské Podhradie/Žiar nad Hronom-castle Šášov; 23 - Širkovcecastle; 24 - Zvolen-Pustý hrad; 25 - Zvolen-Velká Stráž; 26 - Žiar nad Hronom.

firmed by the site of Čebovce-Zámok located most to the south within the studied area (Čambal/Kovár 2014). The upper Hron river basin belongs to the peripheral areas of the Púchov culture. Building fortifications at peripheral zones was typical of the Púchov culture also in its other territories, e.g. in southwestern Slovakia, in the contact zone with the La Tène culture.

\footnotetext{
${ }^{12}$ I wish to thank my colleague Ján Beljak for his help with creation of the registry of sites.

${ }^{13}$ The territory approx. from Hronský Beňadik northeastwards, upstream of the Hron river.
} 
The fortification in Bzenica-Sobotište is located on a small hill (altitude $392 \mathrm{~m}$ a.s.l.). The site was accessible from the north. The perimeter of the rampart, which is $3-4 \mathrm{~m}$, wide is $90 \mathrm{~m}$. The rampart has slid in its top part and created a terrace. It is doubled at the entrance. On the eastern side, it is connected to the eastern rock (Mosný 1988).

The hillfort situated at the site of Kalamárka near Detva is pear-shaped and is 0.9 ha large. It is made of the hilltop plateau in altitude of $808.3 \mathrm{~m}$ a.s.l. which gradually transfers to the Polana massif. It was protected by an approx. $50 \mathrm{~m}$ long rampart from the east (Šalkovský 2001, 39). The site was settled in both Iron ages and started as early as the Bronze Age. The large area of the hillfort, numerous finds, the system of fortifications and documents of metallurgy confirm the importance of the hillfort in the La Tène Period (Šalkovský 1987; 1988; 1990; 1994; 2001; 2002).

The small fortified site in Horná Lehota-Hrádok was located in altitude of $834 \mathrm{~m}$ a.s.l. and covers a rather small area -0.24 ha. Near the site, settlements with probably also La Tène population were discovered (Mácelová 1992; Pieta/Mosný 1996b; 2000; 2001; 2002).

The hillfort in Rybník-Krivín was settled mainly in the Hallstatt Period, but the settlement continues to the La Tène Period. The hillfort consists of six courtyards whose total size is approx. 47-51 ha. Unfortunately, it is not clear how large the area was in the La Tène Period. The highest altitude in the area of the hillfort is $368 \mathrm{~m}$ a.s.l. Several preserved lines of ramparts are hundreds of metres long. There are simple as well as semi-tongs gates. The site was protected by inaccessible terrain from the northwest (Furmánek 1969; Janšák 1929, 27-30; Veliačik/Srnkal Valo 2002).

Dimensions of the fortified area in Horné PršanyHrádok are approx. $60 \times 70 \mathrm{~m}(0.42 \mathrm{ha})$. The terrain divides it into several plateaus. The rampart fortification is visible on the western, less on the northwestern and south-western, side. The altitude is $660.5 \mathrm{~m}$ a.s.l. (Petrikovich 1947; Pieta 1993).

A small fortified site is also located in NemeckáHradisko; the fortification is situated on the rugged mountain ridge in the altitude of approx. $786 \mathrm{~m}$ a.s.l. The ramparts are preserved on two narrower sides. The fortification had two construction phases. Authors of the excavations say that they discovered traces of woods in the rampart. The site is indicated as 'hrádok' (small hillfort) in literature (Mácelovál Mosný/Pieta 1997; Pieta/Mosný 1996a).

The La Tène settlement near Stará Bašta-Pohanský hrad used the extensive old fortification from probably as early as the Late Bronze Age (Furmánek 1996; 1997). The altitude varied between 436.2 and $577.9 \mathrm{~m}$ a.s.1.
The fortified site of Stará Kremnička is known from surveys of P. Mosný and K. Pieta. It is situated $481 \mathrm{~m}$ a.s.l. The ridge on which it is located runs in the NW-SE direction. It is protected by rocks from three sides. Two dump ramparts loom in the terrain on the accessible side (information from K. Pieta; Mosný 1986).

An area of $80 \times 23 \mathrm{~m}$ was fortified at the site on the border between the cadastral areas of Hronská Dúbrava and Trnavá Hora-Hrádok. The enclosed area is approx. 0.8 ha. It was located $416.2 \mathrm{~m}$ a.s.l. and the stone rampart was clearly visible mainly on its northern side. It was dumped from the local andesite rock, which was slag-burnt at the rampart's coping. A hut from the La Tène Period was also discovered there; it was probably destroyed by fire (Pieta 2008, 122; Pieta/Mosný 1990a).

Traces of rampart fortification loom at some places also in Badín (Pieta 2008, 40), Málinec, Lieskovec-Hrádok (approx. $400 \mathrm{~m}$ a.s.l.), Selce-Hrádok (Mácelová 1980; Mosný, undated; Pieta 1989; 1990). A refuge-type settlement is supposed in LučatínHradište (Mosný 1990). A small (still unmeasured) fortified area with ramparts was also located in Čebovce-Zámok, but it was destroyed by medieval construction (Beljak/Beljak Pažinová/Mitáš 2015, 18; Čambal/Kovár 2014).

When building fortifications in the studied area, strategic and well protected sites were occupied. The system of protection often included inaccessible terrain (e.g. Bzenica, Nemecká, Stará Kremnička). At some sites, we can suppose use of older fortification. However, this must be confirmed by further investigation (e.g. Detva, Rybník, Stará Bašta).

According to the above-mentioned typology by K. Pieta, individual fortified settlements can be classified into different categories. The sites in RybníkKrivín and Stará Bašta-Pohanský hrad might belong to hillforts. They are large fortified areas. As for the hillforts of Krivín and Stará Bašta, the size of settlement in the La Tène Period is not clear from the published sources. Both sites were settled also in previous historical periods. The importance of the site in Rybník-Krivín is emphasized by finds of iron slag and flakes which could confirm crafts at the hillfort (Furmánek 1969; Veliačik/Srnka/Valo 2002). The question is whether the site of Detva-Kalamárka can be included in this category, but with regard to the intense settlement in the La Tène Period, I think, I can classify it as a hillfort. Several traces of crafts were also detected in Detva-Kalamárka. The sites of Detva-Kalamárka and Rybník-Krivín are located in the contact zone of the La Tène and Púchov cultures, which confirms their special status.

The area of the fortified site in Čebovce-Zámok has not been exactly defined with regard to the later 
medieval settlement. However, it is probably a site of small size. Despite this, a wide range of finds comes from it. They allow us to assume that it was a central site. Its importance is emphasized by finds of Celtic coins (Čambal/Kovár 2014; Fröhlich 2013). The site could be included in Pieta's category of castella. The small fortification from Horná Lehota-Hrádok might belong to the same category, as traces of metallurgy were discovered there and other unfortified settlements from the La Tène Period are located in its surroundings.

Small fortifications - small hillforts - also occur in the studied area. They are Badín, BzenicaSobotište, Horné Pršany-Hrádok and Hronská Dúbrava-Trnavá Hora-Hrádok; all of them are small fortifications. Further investigation might reveal if open settlements from the La Tène Period were situated in their surroundings. A sandstone crucible for casting metal artefacts was discovered in Horné Pršany-Hrádok, thus, it is legitimate to consider also other than defensive function of the small hillfort, despite its size.

The sites at altitudinally exposed places can be classified into refuges - the castle of Dobrá Niva (537.3 m a.s.l.; Malček 2000) and the castle of Šášov (717.6 m a.s.l.; Pieta 2008, 37).

In the studied territory, the sites of Rybník-Krivín, Stará Bašta-Pohanský hrad and probably also DetvaKalamárka can be classified as large hillforts. Nevertheless, smaller types of fortifications - castella and small hillforts - dominate. A considerably large part of the studied area belongs to the territory of the Púchov culture and its initial development phase in the so-called Pre-Púchov stage. In the environment of the Pre-Púchov stage and Púchov culture, smaller fortifications are predominant (Pieta 1982, 133-146). As for some fortified sites in the Hron and Ipel' river basins, we do not know whether they were permanently settled or used as refuges.

It can be mentioned as an interesting fact that e.g. in England and Wales, it is considered that there is one large hillfort (more than 1 ha), 3 medium and 6 small ones per 10 fortified sites (Harding $2012,9)$. The territory of Wales can be - similarly to our area of interest - characterized as a montane environment. According to this classification, we could record 3 large hillforts (Rybník-Krivín, Stará Bašta-Pohanský hrad, Detva-Kalamárka), 2 medium (Čebovce-Zámok, Horná Lehota-Hrádok) and 21 small fortifications in the studied area. Naturally, the comparison is rather approximate. Nevertheless, we must not forget the pragmatic fact that the number of large hillforts at a specific territory is limited by the capacity and abilities of the com- munity building them. Apart from the number of working hours, we must consider the management of wood, stone and earth - either at the construction of fortification or at its future repairs.

We do not know large open lowland settlements, like those in Levroux, Basel (Gasfabrik), Lovosice, Němčice, Roseldorf or Sajópetri (Fernández-Götz 2018, 132) from the studied territory. ${ }^{14}$ According to the current state of research, there are unfortified settlements, but certain fortification elements can be assumed at them. We have recorded several large Celtic burial grounds in the lower Hron and Ipel' river basins, such as Malé Kosihy (Bujna 1995) and Levice (Samuel 2007). High density of sites from the La Tène Period with limited information value has also been documented. Both these factors can indicate that some central and large settlements might have existed in this territory.

Fortified sites were probably also built on important routes. There is no reconstruction of network of roads or water routes from the La Tène Period in the Carpathian Basin so far. Nevertheless, I assume that the strategy of locating roads in the studied area during the La Tène Period was identical to the strategies in other historical periods, e.g. in the Middle Ages.

P. Ivanič assumes several main directions of early medieval routes in the investigated region. First one was leading from Štúrovo along the right bank of the Hron river to the area of today's Zvolen, from where it continued towards Banská Bystrica (Ivanič 2011, 73). In the Middle Ages, the road diverged in the territory of today's Hronský Beňadik - one part was running further along the Hron river to central Slovakia, the other part turned westwards as far as the region of Nitra (Hunka/Ruttkay 1998, 297-300). The hillfort in Rybník-Krivín is situated there. Other fortified sites are located along the Hron river. The second route also started in the area of Štúrovo and continued to Lučenec along the right bank of the Ipel' river (Ivanič 2011, 73). In the beginning of these two roads course, it is assumed that a used ford was located in the territory of the lower Hron river basin, on the touch of the Hron and Danube, probably somewhere between Mužla and Chlaba (Hunka/Ruttkay 1998, 297). Third route is presented by P. Ivanič in the area of Šahy, where a ford across the Ipel' river is assumed. From there, the road continued to Zvolen. The castella in Čebovce-Zámok was probably located somewhere along this road. P. Ivanič assumes a parallel road on the left bank of the Ipel' river (Ivanic 2011, 73). The castellum in Čebovce can be - despite its small area - an example of an important centre. It had a strategic location; it was situated on a possible important road and

\footnotetext{
${ }^{14}$ We have it in other parts of today's Slovakia, for example Nitra-Zobor-Šindolka (Březinová 2000).
} 
not far from sources of raw materials. We also find indices of minting there.

In the La Tène Period, we must expect occupation of most fortified and upland sites in the studied region in stage LTB, although some sites (DetvaKalamárka, Horná Lehota-Hrádok, Rybník-Krivín) were settled as early as the Hallstatt Period, or even the Bronze Age. Only further research can answer the question whether they were sites with already existent fortification settled on purpose (or sites with remains of old fortification) or people just used the site for its terrain properties. However, continuity of settlement from the Hallstatt Period to the La Tène Period cannot be confirmed. Fragments of vessels with applied decoration in form of animal heads on handles were found in Detva-Kalamárka, Horná Lehota-Hrádok and Nemecká-Hradisko (Mácelová 1992, 72, fig. 32; Pieta/Mosný 1996a, fig. 106: 1; Šalkovský 2002, 103, fig. 4: 1, 2), but their dating is rather wide - from the Hallstatt Period to the Middle La Tène Period (Benediková 2017, 362).

It is mainly the territory of the upper Hron river basin where settlement of most fortified sites survives as late as the end of the La Tène Period (stage LTD). Most fortified settlements in the region of Pohronie exist mainly in the Middle and Late La Tène Period (Kovár 2016). The hillforts in the Ipel' river basin (Čebovce, Málinec) end their existence in stage LTC, which could be associated with the gradual decline and extinction of settlement in the territory of the La Tène culture in southern Slovakia in the Late La Tène Period (Kovár 2016).

We have recorded several sources of ores in the studied territory which might have been used in the La Tène Period. The fortified sites in Stará Kremnička, Šášovské Podhradie, Trnavá Hora and Žiar nad Hronom were situated near the Štiavnické vrchy hills with known sources of various metal ores.

Sources of gold were located near the site of Detva (Miklós/Hrnčiarová 2002, map 23, 89). Other sources of gold are near Lovinobaňa and near the village of Ozdín (area of Uderiná; Rojkovič 1997, 58). The fortified site in Málinec is situated near the village of Ozdín. The small hillfort in Horná Lehota might have used the sources near Čierny Balog (Rojkovič 1997, 60). The sites near Banská Bystrica could have profited from the copper ore in the Špania dolina valley. Traces of metallurgy were detected at the sites of Detva, Horná Lehota and Horné Pršany.

\section{CONSTRUCTION OF FORTIFICATION}

Rampart fortification was recorded at some studied fortifications. Unfortunately, the state of research does not allow solving construction details.
We are not able to describe the character of gates or confirm existence of towers; in most cases, we do not know anything about the construction of rampart body.

At the hillfort of Rybník-Krivín, there are hundreds of metres long lines of ramparts whose height - with regard to the terrain - varies between $1 \mathrm{~m}$ and $10 \mathrm{~m}$. The massiveness of the rampart suggests that it was originally reinforced with an external wooden wall or an internal, possibly box, construction. At some places, multiple rows of dry-laid stones were preserved, probably remains of stone walls on the front side of the most vulnerable sections of the defensive wall. The hillfort was originally enclosed by one peripheral rampart with three gates. Other lines of ramparts with semi-tongs gates were added later. Thus, there were several types of gates - simple gates detected as free spaces in the rampart, or semi-tongs entrances (Janšák 1929, 27-30; Veliačik/Srnka/Valo 2002).

The excavation at the site of Detva-Kalamárka indicate shell constructions of La Tène ramparts. From the outside, one of the La Tène ramparts was made of a massive supporting wall of stone, the core was made of dumped earth reinforced with wood, a narrow stone screen was on the inside. The rampart was built in the Late Bronze Age and rebuilt as early as the Middle Ages. Therefore, information on its width and height can be inaccurate. Moreover, its circumference changed as well - the total width of the rampart body varied from 3 to $8 \mathrm{~m}$ and its preserved height was approx. 1 m (Šalkovský 2002, 101, 102).

A burned rampart of the local andesite quarried stone which was not studied in detail was detected at the hillfort of Hronská Dúbrava-Trnavá HoraHrádok (Pieta/Mosný 1990a; 1999).

\section{CONCLUSION}

Mostly small fortifications of the castella or small hillfort type - according to the classification by K. Pieta - dominate in the investigated territory. With the exception of the sites in Detva and Čebovce, fortifications are situated in the territory of the Púchov culture. With regard to their location (roads, inaccessible terrain), they were probably used mostly for defence. The sites of Detva, Rybník, Stará Bašta and Čebovce could have been centres. However, this hypothesis must be confirmed by further archaeological research. We have not recorded upland sites like Bratislava, Bratislava-Devín, Plavecké Podhradie-Pohanská, Trenčianske BohuslaviceMalovecké, Zemplín from the investigated territory. There are no lowland sites like Němčice-Roseldorf either, but next research can change it. 


\section{BIBLIOGRAPHY}

Audouze/Buchsenschutz 1992 -F. Audouze/O. Buchsenschutz: Towns, villages and countryside of celtic Europe. From the beginning of the second millenium to the end of the first century BC. London 1992.

Bednár/Březinovál Ptáčková 2005 - P. Bednár/G. Březinová/ S. Ptáčková: Neskorolaténske osídlenie hradného návršia v Nitre. Študijné zvesti Aú SAV 37, 2005, 115-185.

Beljak 2006 - J. Beljak: Púchovská kultúra a Germáni na Pohroní v staršej dobe rímskej. In: E. Droberjar/M. Lutovský (eds.): Archeologie barbaru 2005. Sborník př́spěvků $z$ I. protohistorické konference "Pozdně keltské, germánské a časně slovanské osídlení". Kounice, 20-22. září 2005. Praha 2006, 257-272.

Beljak/Kučeráková 2015 - J. Beljak/K. Kučeráková: Vývoj osídlenia na strednom Pohroní od doby laténskej do včasného stredoveku. Študijné zvesti AÚ SAV 57, 2015, 7-56.

Beljak/Beljak Pažinová/Mitáš 2015 - J. Beljak/ N. Beljak Pažinová/V. Mitáš: Stredné a horné Poiplie. Svedectvo archeológie. Archaeologica Slovaca Monographiae. Varia 2. Nitra 2015.

Benadik 1965 - B. Benadik: Die Spätlatènezeitliche Siedlung von Zemplín in der Ostslowakei. Germania 43, 1965, 63-91.

Benediková 2017 - L. Benediková: Kulturkontakte des slowakischen Teils der Westkarpaten während der Hallstattzeit. In: E. Miroššayová/Ch. Pare/S. Stegmann-Rajtár (Hrsg.): Das nördliche Karpatenbecken in der Hallstattzeit. Wirtschaft, Handel und Kommunikation in früheisenzeitlichen Gesellschaften zwischen Ostalpen und Westpannonien. Archaeolingua Series Maior 38. Budapest 2017, 335-381.

Benediková/Kovár 2007 - L. Benediková/B. Kovár: Einige Bemerkungen zu den Funden aus dem Burgwall DetvaKalamárka. Východoslovenský pravek 8, 2007, 143-160.

Benediková/Pieta 2018 - L. Benediková/K. Pieta: Využitie krajiny stredného Liptova v praveku a včasnej dobe dejinnej. Študijné zvesti Aú SAV 63, 2018, 147-196.

Březinová 2000 - G. Březinová: Nitra-Šindolka. Siedlung aus der Latènezeit. Katalog. Archaeologiae Slovaca Monographiae. Catalogi 8. Nitra - Bratislava 2000.

Březinová 2006 - G. Březinová: Sídliská a sídliskové nálezy z laténskej doby na juhozápadnom Slovensku. Študijné zvesti AÚ SAV 40, 2006, 9-50.

Březinová 2010 - G. Březinová: Sídlisko z neskorolaténskej polohy Zámeček v Šuranoch, Nitrianskom Hrádku. In: J. Beljak/G. Březinová/V. Varsik (eds.): Archeológia barbarov 2009. Hospodárstvo Germánov, sídliskové a ekonomické štruktúry od neskorej doby laténskej po včasný stredovek. Zborník referátov z 5. protohistorickej konferencie. Nitra 21.-25. septembra 2009. Archaeologica Slovaca Monographiae. Communicationes 10. Nitra 2010, 113-130.

Březinová 2012 - G. Březinová: The Biritual Cemetery at Šurany-Nitriansky Hrádok, District of Nové Zámky, Slovakia. In: S. Berecki (ed.): Iron Age Rites and Rituals in the Carpathian Basin. Proceedings of the International Colloquium from Târgu Mureş, 7-9 October 2011. Bibliotheca Mvsei Marisiensis. Seria Archaeologica 5. Târgu Mureş 2012, 259-272.

Březinová/Chropovský 2020 - G. Březinová/B. Chropovský: Sídliská z doby laténskej v Nitre. Archaeologica Slovaca Monographiae. Fontes 27. Nitra 2020
Buchsenschutz/Ralston 1981 - O. Buchsenschutz/I. B. M. Ralston: Les forrtifications des âges des métaux. Archéologia 154, 1981, 24-35.

Bujna 1980 - J. Bujna: Sídliskový objekt badenskej kultúry a sídlisko z doby laténskej v Chl’abe. AVANS 1978, 1980, 65-70.

Bujna 1994 - J. Bujna: Mladšia doba železná-laténska na Slovensku. (Prehlad stavu bádania za posledné dve desatročia.) Studia Historica Nitriensia 2, 1994, 7-39.

Bujna 1995 - J. Bujna: Malé Kosihy. Latènezeitliches Gräberfeld. Katalog. Archaeologica Slovaca Monographiae. Catalogi 7. Nitra 1995.

Caesar - G. I. Caesar: Zápisky o vojne v Galii. Preložil J. Hrabovský. Bratislava 2008.

Čambal 2015 - R. Čambal: Datovanie hradiska Pohanská pri Plaveckom Podhradí v dobe laténskej z pohladu archeologických a numizmatických nálezov. Numizmatika 25, 2015, 41-44.

Čambal/Kovár 2014 - R. Čambal/B. Kovár: Keltské nálezy z Čeboviec (okr. Vel'ký Krtíš) a ich regionálne postavenie. In: J. Čižmářová/N. Venclová/G. Březinová (eds.): Moravské kř̌zovatky. Střední Podunají mezi pravěkem a historií. Brno 2014, 305-314.

Čaplovič 1987 - P. Čaplovič: Orava v praveku, vo včasnej dobe dejinnej a na začiatku stredoveku. Martin 1987.

Čižmářr/Kolníková 2006 - M. Čižmář/E. Kolníková: Němčiceobchodní a industrialní centrum doby laténske na Moravě. Archeologické rozhledy 58, 2006, 261-283.

Čižmář/Kolníková/Noeske 2008 - M. Čižmář/E. Kolníková/ H.-Ch. Noeske: Němčice-Víceměřice - ein neues Handels- und Industriezentrum der Latènezeit in Mähren. Vorbericht. Germania 86, 2008, 655-700.

Collis 1975 - J. Collis: Defended Sites of the Late La Tène in the Central and Western Europe. British Archaeological Reports. Supplementary Series 2. Oxford 1975.

Collis/McLaren/Ralston 1976 - J. Collis/I. B. McLaren/I. Ralston: Late La Tène Defence. Germania 54, 1976, 135-146.

Fernández-Götz 2018 - M. Fernández-Götz: Urbanization in Iron Age Europe: Trajectories, Patterns, and Social Dynamics. Journal of Archaeological Research 26, 2018, $117-162$.

Fichtl 2000 - S. Fichtl: La ville celtique. Les oppida de 150 av. J.-C. à 15 ap. J.-C. Paris 2000.

Fröhlich 2013 - J. Fröhlich: Niekol'ko keltských mincí z juhu stredného Slovenska. Hontiansko-novohradsko-gemerský región. Numizmatika 23, 2013, 9-18.

Furman 2016 - M. Furman: Opevnenia na Liptove. Refúgia, hradiská a hrádky od praveku po stredovek. Žilina 2016.

Furmánek 1996 - V. Furmánek: Komplexný archeologický prieskum Pohanského hradu nad Starou Baštou. AVANS 1994, 1996, 51-53.

Furmánek 1997 - V. Furmánek: Ďalšie nálezy z Pohanského hradu nad Starou Baštou. AVANS 1995, 1997, 47.

Furmánek/Marková 1986 - V. Furmánek/K. Marková: Výskum sídliska vo Včelinciach. AVANS 1985, 1986, 80-83.

Furmánek/Sankot 1985 - V. Furmánek/P. Sankot: Nové latenské nálezy na středním Slovensku. Slovenská archeológia 38, 1985, 273-303.

Fusek 1986 - G. Fusek: Záchranný výskum v Bielovciach. AVANS 1985, 1986, 83-85.

Halliday 2019 -S. Halliday: How many hillforts are there in Scotland? Revisited. In: Romankiewicz et al. 2019, 37-51. 
Hanuliak 1989 - M. Hanuliak, M.: Praveké, včasnodejinné a stredoveké osídlenie v Chlabe. Slovenská archeológia 37, 1989, 151-212.

Harding 2012 - D. W. Harding: Iron Age Hillforts in Britain and Beyond. Oxford 2012.

Harding/Sievers/Venclová 2006 - A. Harding/S. Sievers/ N. Venclová (eds.): Enclosing the Past. Inside and Outside in Prehistory. Sheffield Archaeological Monographs 15. Sheffield 2006.

Hérodotos - Hérodotos: Dějiny aneb Devět knih dějin nazvaných MÚSY. Přeložil J. Šonka. Praha 2004.

Hunka/Ruttkay 1998 - J. Hunka/M. Ruttkay: Historické komunikácie na území stredovekého Slovenska. Archaeologia Historica 23, 1998, 295-302.

Ivanič 2011 - P. Ivanič: Stredoveká cestná siet' na Pohroní a Poiplí. Nitra 2011.

Janšák 1929 - Š. Janšák: Slovenské hradiská z doby halštatskej. Sborník muzeálnej slovenskej spoločnosti 23, 1929, 1-32.

Kovács 1982 - Š. Kovács: Keltská chata a nálezy z doby rímskej v Barci. AVANS 1981, 1982, 155-163.

Kovács 1984 - Š. B. Kovács: Výskumy a prieskumy múzea v okrese Rimavská Sobota. AVANS 1983, 1984, 45-51.

Kovár 2016 - B. Kovár: The Settlements of the Hron, Ipel', Slaná and Rimava River Basins during the La Tène Period. In: S. Berecki (ed.): Iron Age Chronology in the Carpathian Basin. Proceesings of the Internagtional Coloquium from Târgu Mureş 8-10 October 2015. Bibliotheca Mvsei Marisiensis. Series Archaeologica 12. Târgu Mureş 2016, 219-234

Kujovský 1985 - R. Kujovský: Záchranný výskum v Tekovskom Hrádku. AVANS 1984, 1985, 139.

Kuzmová 1980 - K. Kuzmová: Nížinné sídliská z neskorej doby laténskej v strednom Podunajsku. Slovenská archológia 28, 1980, 313-340.

Luštíková/Miroššayová 2009 - L. Luštíková/E. Miroššayová: Príspevok k osídleniu polohy Hradisko v Zemplíne. Východoslovenský pravek 9, 2009, 159-168.

Mácelová 1980 - M. Mácelová: Nové nálezy lužickej kultúry a púchovskej kultúrnej skupiny z hrádku v Balážoch. AVANS 1979, 1980, 134-136.

Mácelová 1992 - M. Mácelová: Nálezy z Hornej Lehoty. AVANS 1990, 1992, 72, 73 .

Mácelová 1995 - M. Mácelová: Prvé nálezy na hradisku v Nemeckej. AVANS 1993, 1995, 94.

Mácelová/Mosný/Pieta 1997 -M. Mácelová/P. Mosný/K. Pieta: Zistovací výskum na hradisku v Nemeckej. AVANS 1995, 1997, 130, 131.

Malček 2000 - R. Malček: Zbery v okresoch Zvolen a Detva. AVANS 1998, 2000, 128, 129.

Miklós/Hrnčiarová 2002 - L. Miklós/T. Hrnčiarová (eds.): Atlas krajiny Slovenskej republiky. Bratislava - Banská Bystrica 2002.

Miroššayová 2019 - E. Miroššayová: Laténske osídlenie na Východoslovenskej nížine. In: N. Beljak Pažinová/ D. Repka (red.): Sedem kruhov Jozefa Bujnu. Studia Historica Nitriensia 23. Supplementum 2. Nitra 2019, 237-253. DOI: https://doi.org/10.17846/SHN.2019.23.S.237-253

MiroššayoválČaplovič 1991 - E. Miroššayová/D. Čaplovič: Najnovšie výsledky výskumu včasnodejinného a stredovekého osídlenia v Zemplíne. Východoslovenský pravek 3, 1991, 115-132.

Neustupný 2006 - E. Neustupný: Enclosures and fortifications in Central Europe. In: Harding/Sievers/Venclová 2006, 1-4.
Novotný 1955 - B. Novotný: Nové laténske nálezy na dolnom Pohroní. Archeologické rozhledy 7, 1955, 781-794.

Paulík 1976 - J. Paulík: Keltské hradisko Pohanská v Plaveckom Podhradí. Bratislava 1976.

Pieta 1982 - K. Pieta: Die Púchov-Kultur. Archaeologica Slovaca Monographiae. Studia 1. Nitra 1982.

Pieta 1990 - K. Pieta: Nové nálezy na hrádku v Selciach pri Banskej Bystrici. AVANS 1988, 1990, 138, 139.

Pieta 1993 - K. Pieta: Hradisko a výšinné sídlisko z doby laténskej a rímskej v Horných Pršanoch. AVANS 1992, 1993, 106, 107.

Pieta 2001 - K. Pieta: Jan Filip a neskorolaténske osídlenie Slovenska. Archeologické rozhledy 53, 2001, 780-788.

Pieta 2008 - K. Pieta: Keltské osídlenie Slovenska. Mladšia doba laténska. Archaeologica Slovaca Monographiae. Studia 11. Nitra 2008.

Pieta 2010 - K. Pieta: Die Keltische Besiedlung der Slowakei. Jüngere Latènezeit. Archaeologica Slovaca Monographiae. Studia 12. Nitra 2010.

Pieta/Mosný 1990a - K. Pieta/P. Mosný: Hradisko pri Trnavej Hore. AVANS 1988, 1990, 139.

Pieta/Mosný 1990b - K. Pieta/P. Mosný: Prieskum sídlisk z doby rímskej na strednom Pohroní. AVANS 1988, 1990, 139, 140.

Pieta/Mosný 1996a - K. Pieta/P. Mosný: Laténske hradisko so stredovekým osídlením pri Nemeckej. AVANS 1994, 1996, 140.

Pieta/Mosný 1996b - K. Pieta/P. Mosný: Nové nálezy z laténskeho hradiska pri Hornej Lehote. AVANS 1994, 1996, 140-142.

Pieta/Mosný 1999 - K. Pieta/P. Mosný: Hrádok púchovskej kultúry pri Hronskej Dúbrave. AVANS 1997, 1999, 138.

Pieta/Mosný 2000 - K. Pieta/P. Mosný: Sídlisko z doby železnej v Hornej Lehote. AVANS 1999, 2000, 104, 105.

Pieta/Mosný 2001 - K. Pieta/P. Mosný: Halštatské a laténske osídlenie v Hornej Lehote. AVANS 2000, 2001, 160, 161.

Pieta/Mosný 2002 - K. Pieta/P. Mosný: Výskum v Hornej Lehote. AVANS 2001, 2002, 161, 162.

Pieta/Plachá/Hlavicová 1986 - K. Pieta/V. Plachá/J. Hlavicová: Devín v dobe laténskej a rímskej. In: V. Horváth (zost.): Najstaršie dejiny Bratislavy. Referáty zo sympózia 28.-30. októbra 1986. Bratislava 1986, 86-101.

Plachá 1972 - V. Plachá: Archeologický výskum devínskeho hradu v rokoch 1966-1970. Archeologické rozhledy 24, 1972, 73-78.

Plachá 1991 - V. Plachá: Devín. In: B. Polla/A. Vallašek (zost.): Archeologická topografia Bratislavy. Bratislava 1991, 20-23.

Posluschny 2019 - A. G. Posluschny: Does fortified always equate do defensive? Some thoughts on the fortification systems of the Glauberg hillfort. In: Romankiewicz et al. 2019, 9-18.

Rojkovič 1997 - I. Rojkovič: Rudné ložiská Slovenska. Bratislava 1997.

Romankiewicz et al. 2019 - T. Romankiewicz/M. Fernádez-Götz/G. Lock/O. Büchsenschütz (eds): Enclosing space, opening new Gorund. Iron Age studies from Scotland to mailand Europe. Oxford - Philadelphia 2019.

Rusnák 2007 - R. Rusnák: Objekty zo staršej a mladšej doby železnej zo Stránskej. Východoslovenský pravek 8, 2007, 59-75.

Ruttkay, in press - M. Ruttkay: Výskum na hradisku Zemplín. AVANS 2017, in press.

Salač 2005 - V. Salač: Vom Oppidum zum Einzelgehöft und zurück - zur Geschichte und dem heutigen Stand 
der Latèneforschung in Böhmen und Mitteleuropa. Alt Thüringen 38, 2005, 279-300.

Salač 2019 - V. Salač (ed.): Atlas pravěkých a raně středověkých hradišt' $v$ Cechách. Praha 2019.

Šalkovský 1994 - P. Šalkovský: Hradisko v Detve. Materialia Archaeologica Slovaca 11. Nitra 1994.

Šalkovský 2001 - P. Šalkovský: Výšinné hradisko v Detve osídlenie v mladšej a neskorej dobe bronzovej. Slovenská archeológia 49, 2001, 39-58.

Šalkovský 2002 - P. Šalkovský: Výšinné hradisko v Detve - protohistorické osídlenie. Slovenská archeológia 50, 2002, 99-126.

Samuel 2007 - M. Samuel: Nová polykultúrna lokalita v Leviciach. AVANS 2005, 2007, 173, 174.
Smrž 1991 -Z. Smrž: Výšinné lokality mladší doby kamenné až raného středověku v severozápadních Čechách. Pokus o sídelně historické hodnocení. Archeologické rozhledy 43, 1991, 63-89.

Točík 1981 - A. Točík: Nitriansky Hrádok-Zámeček. Bronzezeitliche befestige Ansiedlung der Mad'arovce-Kultur. I, II. Tafeln, Pläne. Materialia Archaeologica Slovaca 3. Nitra 1981.

Veliačik/Srnka/Valo 2002 - L. Veliačik/F. Srnka/J. Valo: Hradisko Krivín v Rybníku. Študijné zvesti AÚ SAV 35, 2002, 27-42.

Vendtová 1964 - V. Vendtová: Výskum v Slovenských Ďarmotách roku 1962. Archeologické rozhledy 16, 1964, 347-369.

\section{UNPUBLISHED SOURCES}

Budinský-Krička 1947 - V. Budinský-Krička: Bánska Bystrica. Výskumná správa 289/47. Dokumentácia AÚ SAV Nitra.

Furmánek 1969 - V. Furmánek: Rybník. Nitra 1969. Výskumná správa 4782/69. Dokumentácia AÚ SAV Nitra.

Mosný 1986 - P. Mosný: Manuscript SAS 121. Výskumná správa 36/86. Dokumentácia AÚ SAV Nitra.

Mosný 1988 - P. Mosný: Manuscript SAS 137/88. Dokumentácia AÚ SAV Nitra.

Manuscript accepted 12. 9. 2021

Translated by Viera Tejbusová and author
Mosný, undated - P. Mosný: Manuscript SAS 138. Dokumentácia AÚ SAV Nitra.

Petrikovich 1947 - J. Petrikovich: Horné Pršany. Výskumná správa 428/47. Dokumentácia AÚ SAV Nitra.

Pieta 1989 - K. Pieta: Selce. Nitra 1989. Výskumná správa 12442/89. Dokumentácia AÚ SAV Nitra.

Vladár 1962 - J. Vladár: Čaka. Nitra 1962. Výskumná správa 184/62. Dokumentácia AÚ SAV Nitra.

Mgr. Branislav Kovár, PhD.

Archeologický ústav SAV

Akademická 2

SK - 94921 Nitra

brano.kovar@gmail.com 